\title{
Study on the Control of Polluted Odour Gas by Biological Treatment Technology
}

DOI: 10.15255/KUI.2017.006 KUI-26/2017

Original scientific paper Received March 1, 2017 Accepted June 26, 2017

\author{
W. Dong* \\ College of Environment, Zhejiang University of Technology, Hangzhou, \\ Zhejiang, 310 014, P.R. China
}

This work is licensed under a Creative Commons Attribution 4.0

\begin{abstract}
$\|$ Abstract
In order to improve the quality of the environment as well as its purification capacity, to reduce environmental costs and achieve clean and efficient management of malodorous gas pollution, on the basis of fully understanding the theory of biotechnology, this paper presents the research of biotechnology to control the pollution of malodorous pollutants. In this research, the biofiltration method was used to control the odour gas ammonia produced in waste composting, which can effectively purify gases, with a high ammonia removal rate. One week after the ammonia removal experiment, the removal rate was detected to be around $79.3 \%$. Twenty-four days after the experiment, the removal rate stabilized at around $98 \%$. Through the test of $\mathrm{pH}$ value of nutrient solution, it was found that the change in $\mathrm{pH}$ value corresponded to the increase in removal rate. There are many advantages of applying biotechnology to filter malodorous polluted gases, such as low energy consumption, high degree of purification, good environmental compatibility, simple operation and maintenance, and no secondary pollution. Therefore, it has good application prospects.
\end{abstract}

$\|$ Keywords

Biotechnology, malodorous gas, biological filtration, ammonia, pollution control

\section{Introduction}

With the development of economy and the improvement of people's living standard, the problem of domestic waste has become increasingly prominent. Municipal solid waste disposal methods include composting, incineration and landfill. Currently, the composting method that has a high harmlessness degree is mainly adopted. However, the garbage composting process produces a large amount of ammonia-based malodorous gases that can cause environmental destruction, which has deeply concerned many scholars. R. Kikuchi ${ }^{1}$ confirmed through an experiment that foul air containing $600 \mathrm{mg} \mathrm{l}^{-1}$ ammonia could be cleaned using soil filter with a removal rate of $98.5 \%$. In addition, the concentrations of methyl mercaptan, dimethyl sulphide, dimethyl disulphide, formaldehyde, and trimethylamine have also been significantly reduced. $M$. Dehghani et al. ${ }^{2}$ studied the feasibility of using a trickling filter to remove faecal gases from septic tanks. The study used a drip system to measure hydrogen sulphide and ammonia concentrations to control the odour and determine the ability of filtration. Under optimum conditions, the filter bed with an empty bed residence time of $200 \mathrm{~s}$ was able to remove $99.9 \% \mathrm{H}_{2} \mathrm{~S}$, suggesting that trickle filters were an affordable and cost-effective way to remove hydrogen sulphide from septic tanks. Q. D. Zhang et al. ${ }^{3}$ discussed the filler of a composite biotin filter inoculated with toluene degraded microorganisms, which was composed of sawdust, peat and compost, with high organic matter content, high specific surface area, good water retention,

*Wen Dong

e-mail: dongwen.zjut@yahoo.com good permeability, diversified microbial systems, and intrinsic nutrition. They found that it could reach a removal rate of $92 \%$ at different toluene concentrations. Therefore, the application of the biological treatment technology to control polluted malodorous gases has the advantages of low cost, simple operation, convenient maintenance, no secondary pollution, and it can purify the polluted gases cleanly and efficiently, thereby improving the quality of the environment and the living standards of people.

\section{Biological filtration technology}

The biological method ${ }^{4}$ refers to the process that converts contaminants into harmless or less harmful substances with the microbial oxidation and decomposition effects. The gas contaminants are transferred through the gas and water interfaces to the biofilm attached to the surface of the filler; the microorganism in the biofilm takes the gas pollutants as its substrate for growth and reproduction, and decomposes macromolecules or complex organic molecules into $\mathrm{CO}_{2}, \mathrm{H}_{2} \mathrm{O}$ and other inorganic substances through catabolism in order to reach the purpose of purifying the polluted gases. Currently, the main malodorous gas biological control technology includes biological scrubbing tow$\mathrm{er}^{5}{ }^{5}$ biological filter tower, ${ }^{6}$ and bio-trickling filter. ${ }^{7}$ Despite its advantages, the biological filtration method also has its shortcomings, such as difficulty in controlling the degradation parameters, high risk of collapse of the filler, etc. As shown in Fig. 1, the biological filtration ${ }^{8}$ method is one of many methods used for separation in biotechnology, that passes the malodorous gas with humidifying treatment into 
a biofilter filled with filler to contact with the biological membrane attached to the surface of the filler in order to be converted into simple inorganic matter after being degraded by the microorganism, and discharges the purified gas from the top of the filter. Its characteristics are that biological phase and liquid phase are not flowing and there is only one reactor-biofilter. The filler of the biofilter needs to maintain a certain $\mathrm{pH}$ range and nutrition to ensure metabolic requirements. The biological filtration method uses a combination of liquid absorption and biological treatment, and its essence of removing pollutants is to take the malodorous gas as the nutrient for the microbial life activities so that it is absorbed, metabolized, and utilized by microorganisms. When the biodegradation of malodorous gases is carried out using biofilter, the physical and chemical properties of the contaminants may have a certain effect on the treatment effect of the reactor. Therefore, it is essential to select the appropriate microorganisms to ensure the deodorization efficiency. The performance of the reactor in biological filtration is important, and the performance parameters of the biofilter include residence time, removal load, ${ }^{9}$ removal rate, etc. The removal load of the pollutant volume refers to the amount of removed contaminants per unit per volume by the packing layer, which is the most important parameter for evaluating the filter performance.

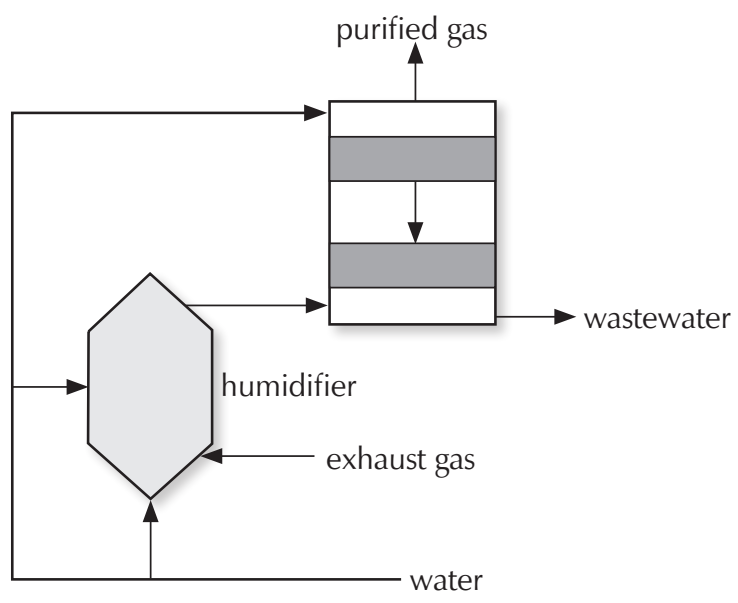

Fig. 1 - Biofiltration process

\section{Application of the biological filtration method in malodorous gases}

\subsection{The origin of malodorous gas}

The national standard GB14554-93 defines a malodorous gas $^{10}$ as a gaseous substance that stimulates the olfactory organ, causes unpleasant mood, and damages the living environment. It is mainly derived from industrial production, municipal sewage, sludge treatment, and waste disposal facilities. According to their composition, odour gases can be divided into five categories: sulphur compounds, nitrogen compounds, halogen and its derivatives, hydro- carbons, and oxygen-containing organic matter. Different treatment facilities and processes will produce different malodorous gases. For example, sewage treatment plants will produce $\mathrm{H}_{2} \mathrm{~S}$ odour, waste composting will produce $\mathrm{NH}_{3}$, amines, sulphides, fatty acids and other odours, sludge drying will produce mercaptans and dimethyl sulphide gas. This study is aimed at the control experiment of $\mathrm{NH}_{3}$ produced during the process of waste composting. $\mathrm{NH}_{3}$ is one of the major components of malodorous gases and has corrosive and stimulating effects on the exposed skin tissues. When its concentration is too high, it is even likely to cause cardiac arrest and respiratory arrest through the reflex of the trigeminal nerve endings. ${ }^{11}$

\subsection{Malodorous gas treatment experiment with filter}

\subsubsection{Experimental purpose}

In order to verify the effect of biological filtration on the filtration of malodorous gases, $\mathrm{NH}_{3}$ removal experiments were carried out.

\subsubsection{Experimental materials and methods}

\section{(1) Degrading bacteria}

The activated sludge ${ }^{12}$ of an aeration tank of a domestic sewage treatment plant in Hangzhou, Zhejiang province was adopted in this experiment to treat the sewage containing metabolic waste and food residues. The activated sludge had high microbial content, and the main microorganisms were aerobic isolates, yeasts, etc. The degrading bacteria with denitrification ability were screened out by the domestication breeding ${ }^{13}$ method and placed in the filling layer for growth and biofilm culturing.

\section{(2) Waste gas}

The exhaust gas used in the experiment was the $\mathrm{NH}_{3}$ exhaust with a high purity after dilution. The composition and proportion of the circulating nutrient solution were as follows: $\mathrm{K}_{2} \mathrm{HPO}_{4} 1.2 \mathrm{~g} \mathrm{l}^{-1}, \mathrm{NaHCO}_{3} 1 \mathrm{~g} \mathrm{l}^{-1}$, $\mathrm{MgCl}_{2} \cdot 6 \mathrm{H}_{2} \mathrm{O} 0.2 \mathrm{gl}^{-1}, \mathrm{NaCl} 0.07 \mathrm{gl}^{-1}$, glucose $0.02 \mathrm{gl}^{-1}$.

\section{(3) Biological filter tower}

The tower is divided into two layers, placed with two layers of packing which are supported by a plexiglass plate. A layer of gauze is paved on the gas plate and multiple pores are opened on the plate to avoid obstruction. For the selection of packing material, compost and microporous medical stone were chosen because of their rough surface and large specific surface area which is conducive to biofilm attachment and their low price as well as their capacity to release a variety of trace elements to provide inorganic nutrients for the biofilm. When used, the medical stone is crushed and thoroughly washed with distilled water and dried at $105^{\circ} \mathrm{C}$ for $24 \mathrm{~h}$ for sieving. The medical stone particles with a particle size of 4 to $5 \mathrm{~mm}$ are taken as the packing material of the biological filter. 


\section{(4) Degradation principle}

Nitrification is completed based on the activities of nitrifying bacteria. ${ }^{14}$ The reaction process of nitrite bacteria oxidating ammonia is as follows:

$$
2 \mathrm{NH}_{3}+3 \mathrm{O}_{2} \rightarrow 2 \mathrm{HNO}_{2}+2 \mathrm{H}_{2} \mathrm{O} \quad \Delta H<0
$$

The synthesis of organic matter is as follows:

$$
6 \mathrm{CO}_{2}+6 \mathrm{H}_{2} \mathrm{O} \rightarrow \mathrm{C}_{6} \mathrm{H}_{12} \mathrm{O}_{6}+6 \mathrm{O}_{2}
$$

Then, the nitrifying bacteria oxidate the nitrous acid into nitric acid as follows:

$$
\begin{gathered}
2 \mathrm{HNO}_{2}+2 \mathrm{H}_{2} \mathrm{O} \rightarrow 2 \mathrm{HNO}_{3}+4 \mathrm{H}^{+}+4 \mathrm{e}^{-} \\
4 \mathrm{H}^{+}+4 \mathrm{e}^{-}+\mathrm{O}_{2} \rightarrow 2 \mathrm{H}_{2} \mathrm{O} \quad \Delta H<0 \\
\text { i.e., } 2 \mathrm{HNO}_{2}+\mathrm{O}_{2} \rightarrow 2 \mathrm{HNO}_{3} \quad \Delta H<0
\end{gathered}
$$

Then, nitrifying bacteria use the ATP formed in the above reaction to assimilate carbon dioxide and synthesize intracellular organic matter as follows:

$$
6 \mathrm{CO}_{2}+6 \mathrm{H}_{2} \mathrm{O} \rightarrow \mathrm{C}_{6} \mathrm{H}_{12} \mathrm{O}_{6}+6 \mathrm{O}_{2}
$$

The biodegradation process of $\mathrm{NH}_{3}$ is as follows:

$$
\mathrm{NH}_{3}(\mathrm{~g}) \Rightarrow \mathrm{NH}_{4}(\mathrm{OH}) \Rightarrow \mathrm{NO}_{2}^{-} \Rightarrow \mathrm{NO}_{3}^{-}
$$

After entering the bioreactor, $\mathrm{NH}_{3}$ was adsorbed on the surface of the moist biofilm through the gas film and transferred from the gas phase into the liquid phase. Under the impetus of liquid concentration, it entered the biofilm through the liquid film and then degraded by microorganisms. Afterwards, the nitrosomonas within the biofilm oxidated and decomposed $\mathrm{NH}_{4}{ }^{+}$into $\mathrm{NO}_{2}{ }^{-}$. Then, was again oxidated and decomposed by nitrifying bacteria into $\mathrm{NO}_{3}{ }^{-}$.

\section{(5) Processing flow}

After being humidified, the malodorous gas enters into the biofilter and the contaminants in the gas are attached to the biofilm ${ }^{15}$ of the filler layer due to diffusion and absorbed by the microorganisms and decomposed into water and other odourless substances in the biological cells. Finally, the purified gas is discharged from the top.

\section{(6) Detection method}

The concentration of ammonia is mainly determined by Nessler's reagent colorimetric method. ${ }^{16}$ Mercury(II) iodide and potassium iodide alkaline solution reacts with ammonia to produce a reddish brown colloidal compound whose chroma is proportional to the ammonia content. Then, the absorbance can be measured in the wavelength range of 410-425 nm. Then the mass concentration of ammonia is calculated through the following formula:

$$
\gamma\left(\mathrm{NH}_{3}\right)=\frac{\left(A-A_{0}-a\right) \cdot V_{S}}{b \cdot V_{\text {nd }} \cdot V_{0}}
$$

where $V_{\mathrm{s}}$ refers to the total volume of sample; $V_{0}$ refers to the volume of the liquid taken for analysis; $V_{\text {nd }}$ refers to the volume of gas at standard state $(101.325 \mathrm{kPa}, 273 \mathrm{~K})$; $A$ refers to the absorbance of the sample solution; $A_{0}$ refers to the blank absorbance of the absorbent liquid prepared together with the samples; a refers to the regression line intercept, and $b$ refers to the regression line slope.

The ammonia removal rate is the ratio of ammonia concentration difference between the inlet and outlet of the purification device and the inlet ammonia concentration, which can be calculated through the following formula:

$$
\eta=\frac{C_{\text {in }}-C_{\text {out }}}{C_{\text {in }}}
$$

where $c_{\text {in }}$ and $c_{\text {out }}$ refer to the inlet and outlet ammonia concentration, respectively. However, ammonia is easily soluble in water, so there is a certain error. Depending on the removal rate, the filtration effect and the degree of purification can be obtained. The $\mathrm{pH}$ of the nutrient solution in the filter is measured with a $\mathrm{pH}$ meter.

\subsubsection{Experimental process}

Before the experiment, the reaction temperature was maintained at around $25{ }^{\circ} \mathrm{C}$. Configure the buffer solution and set the initial $\mathrm{pH}$ value at 6.8. In order to prevent the filter bed acidification, add lime as a buffer to the filter media. During the experiment, the $\mathrm{pH}$ value increased first and then decreased. The nutrient solution spray was $60 \mathrm{ml} \mathrm{min}{ }^{-1}$. The intermittent ventilation oxygen supply mode was adopted and the ventilation time and number were adjusted according to the reaction that was carried out for 21 days. After starting the filter, the wetted treated exhaust gas was passed through the bottom perforated tube into a biofilter which had been acclimated. The parameters were strictly controlled and real-time detection of import and export of exhaust gas concentration, $\mathrm{pH}$ value, and dissolved oxygen were realized through the ammonia detector and Nessler reagent colorimetric method. ${ }^{15}$

\subsubsection{Experimental results}

After a week of domestication, the gas concentration at the inlet and outlet of the equipment detected was compared. The concentration of ammonia detected at the inlet of the biological filter was $4.2 \mathrm{mg} \mathrm{m}^{-3}$, and the detected odour concentration was 2500 dimensionless. The ammonia concentration was $0.87 \mathrm{mg} \mathrm{m}^{-3}$ and the odour concentration was 37 dimensionless. The removal rate of ammonia gas was about $79.3 \%$ after one week. It can be seen that it is feasible to remove ammonia gas by the biological filtration method, but the specific purification effect needs to be further prolonged. The filter run time was extended to 21 days to study the volume removal load, ammonia removal rate, and $\mathrm{pH}$ changes. The odour load into the biofilter is controlled by adjusting the intake air concentration and intake air flow of the odour, and the trend is observed. During the 21 days of the biofilter operation, the volume of $\mathrm{NH}_{3}$ removed by the filter increased with time. 


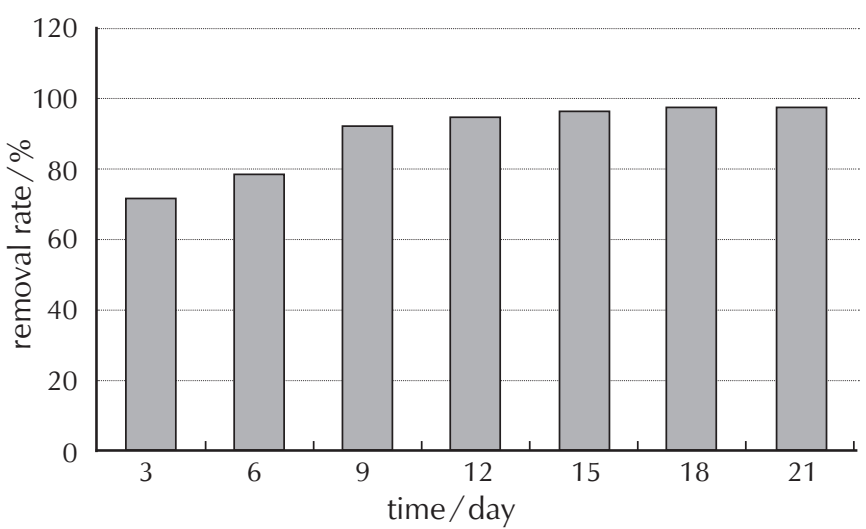

Fig. 2 - Ammonia removal rate changes

As shown in Fig. 2, during the operation of the filter, the removal rate of $\mathrm{NH}_{3}$ increases as the run time increases, because the purification ability is weak at the initial stage since the biofilm is not yet formed. In the meantime, the capacity of the biofilter increases as the biomass increases with time. In the first 9 days, the growing rate is obvious, which is $72 \%$ on the third day, $78.7 \%$ on the sixth day, and $92.4 \%$ on the ninth day, which tends to ease afterwards when the biofilm is basically formed, which marks the end of the start-up phase of the filter. After the biological filter treatment, the removal rate of ammonia is up to $98 \%$, reaching the odorous pollutant discharge standards.

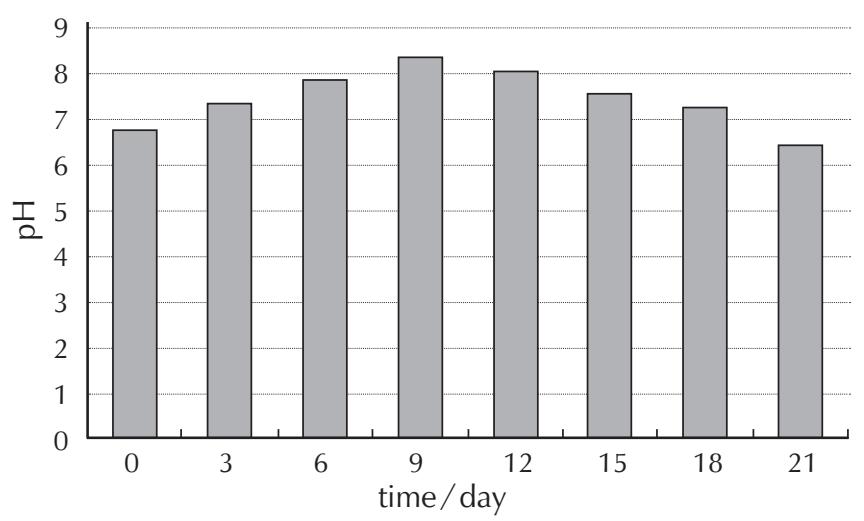

Fig. 3 - Nutrient solution $\mathrm{pH}$ changes

As shown in Fig. 3, the $\mathrm{pH}$ of the circulating nutrient solution shows an obvious trend from increasing to decreasing, which firstly increased to 8.4 on the $15^{\text {th }}$ day from the initial value of 6.8 , and then decreased to 5.9 , gradually turning into acid state. Ammonia is easy to dissolve in water and initial ammonia concentration is too high, while the microbial reaction is slow. Therefore, some odour that is not degraded timely will produce a large number of hydroxide anions after dissolving in water, resulting in an increase in the $\mathrm{pH}$ value of the filler in the biological filter. With the further progress of microbial reactions, ammonia will gradually be degraded, with the $\mathrm{pH}$ value declining gradually, which will have a direct impact on the growth of microorganisms and the ammonia removal rate.

\section{Discussion and conclusion}

In this paper, the biofiltration method was used to control the ammonia produced during the composting process. After testing, the purification capacity of the biological filter increased with the increase in running time. After treatment of waste gas, the ammonia removal rate was up to $98 \%$, with no secondary pollution, proving that biological filtration is a clean and efficient pollution control technology. However, there are also problems of long membrane-forming time, acidification of the nutrient solution and waste liquor recovery, etc. Therefore, future research needs to be carried out to solve these problems.

\section{List of abbreviations and symbols}

A - absorbance of the sample

$A_{0}$ - absorbance of the blank absorption liquid

a - regression line intercept

b - regression line slope

$C_{\text {in }} \quad$ - inlet ammonia concentration

$C_{\text {out }}$ - outlet ammonia concentration

$V_{0}$ - volume of the liquid taken for analysis

$V_{\text {nd }}$ - volume of gas

$V_{\mathrm{S}}$ - volume of sample

$\gamma$ - mass concentration

$\eta \quad$ - ammonia removal rate

\section{References Literatura}

1. R. Kikuchi, Pilot-scale test of a soil filter for treatment of malodorous gas, Soil Use Manage. 16 (3) (2010) 211-214, doi: https://doi.org/10.1111/j.1475-2743.2000.tb00195.x.

2. M. Dehghani, M. M. Taghizadeh, Designing biological filters to eliminate odors in septic tank based on the amount of hydrogen sulphide, Jundishapur J. Health Sci. 5 (2) (2013) 7987, url: http://jjhsci.com/?page $=$ article\&article_id $=26887$.

3. Q. D. Zhang, S. H. Guo, D. F. Zhao, Treatment of Petrochemical Malodorous Gases by Biofilter Packed with Complex Filler, Adv. Mat. Res. 356-360 (10) (2012) 1298-1301, doi: https://doi.org/10.4028/www.scientific.net/AMR.356360.1298.

4. K. X. Yang, L. Li, J. X. Liu, Review on biological techniques for treatment of VOCs and odors, Environ. Eng. 34 (3) (2016) 107-111, doi: https://doi.org/10.13205/j.hjgc.201603022.

5. O. D. Frutosa, G. Quijanoa, R. Péreza, R. Muñoza, Simultaneous biological nitrous oxide abatement and wastewater treatment in a denitrifying off-gas bioscrubber, Chem. Eng. J. 288 (2016) 28-37, doi: https://doi.org/10.1016/j. cej.2015.11.088.

6. L. Pharand, M. I. V. Dyke, W. B. Anderson, P. M. Huck, As- 
sessment of Biomass in Drinking Water Biofilters by Adenosine Triphosphate, J. Am. Water Works Assoc.106 (10) (2014) E433-E444, doi: https://doi.org/10.5942/jawwa.2014.106.0107.

7. G. Rodriguez, A. D. Dorado, M. Fortuny, D. Gabriel, X. Gamisans, Biotrickling filters for biogas sweetening: oxygen transfer improvement for a reliable operation, Process Saf. Environ. 92 (3) (2014) 261-268, doi: https://doi.org/10.1016/j. psep.2013.02.002.

8. M. Rattier, J. Reungoat, J. Keller, W. Gernjak, Removal of micropollutants during tertiary wastewater treatment by biofiltration: Role of nitrifiers and removal mechanisms, Water Res. 54 (4) (2014) 89-99, doi: https://doi.org/10.1016/j. watres.2014.01.030.

9. A. Fernandes, D. Santos, M. J. Pacheco, L. Ciríaco, A. Lopes, Nitrogen and organic load removal from sanitary landfill leachates by anodic oxidation at Ti/Pt/PbO 2 Ti/Pt/SnO ${ }_{2}-\mathrm{Sb}_{2} \mathrm{O}_{4}$, and Si/BDD, Appl. Catal. B Environ. 148-149 (6) (2014) 288294, doi: https://doi.org/10.1016/j.apcatb.2013.10.060.

10. L. Yang, Y. F. Jiang, J. M. Cheng, X. Zhang, S. X. Zhang, The design of the microfluidic chip for on-line monitoring of malodorous gases and experimental studies, Proceedings of 2014 International Conference on Environmental Science and Biological Engineering (ESBE2014), 2014, pp. 843-850, doi: https://doi.org/10.2495/ESBE141071.

11. J. J. Ma, Effects and countermeasures of ammonia in air, Sci. Res. 12 (2016) 00288-00288, url: http://xueshu.baidu.com.

12. B. Yu, J. Xu, H. Yuan, Z. Lou, J. Lin, N. Zhu, Enhancement of anaerobic digestion of waste activated sludge by electrochemical pretreatment, Fuel 130 (2014) 279-285, doi: https://doi.org/10.1016/j.fuel.2014.04.031.

13. D. Dong, B. Chen, P. Chen, Bacterial Acclimation Inside an Aqueous Battery, Plos One 10 (6) (2015) e0129130, doi: https://doi.org/10.1371/journal.pone.0129130.

14. W. R. Xuan, M. J. Shan, C. F. Zheng, Effects of pH and Alkalinity on Biological Nitrification, Fuel Chem. Ind. 43 (3) (2012) 36-38, doi: https://doi.org/10.16044/j.cnki.rlyhg.2012.03.081.

15. S. K. Abbas, S. S. Rengitham, Development of colorimetric method for the quantification of methyl salicylate in bulk and formulations, J. Appl. Pharm. Sci. 4 (9) (2014) 52-55, doi: https://doi.org/10.7324/JAPS.2014.40909.

16. T. Chen, Y. B. Liu, H. M. Yuan, Determination of Ammonia Nitrogen in Sewage by Nessler 's Reagent Colorimetric Method, China's New Technol. New Prod. 3 (2010) 18-18, doi: https://doi.org/10.13612/j.cnki.cntp.2010.03.005.

\section{SAŽETAK \\ Uklanjanje neugodnog mirisa otpadnog plina biološkom obradom Wen Dong}

U radu je predstavljena biotehnologija uklanjanja plinova neugodna mirisa. Cilj istraživanja bio je popraviti kvalitetu okoliša, povećati kapacitet pročišćavanja, smanjiti troškove vezane uz očuvanje okoliša, te postići čistu i učinkovitu kontrolu onečišćenja plinovima s neugodnim mirisom.

Biofiltracijom je pročišćen otpadni plin s amonijakom. Nakon sedam dana uklonjeno je 79,3\% amonijaka, a nakon 24 dana udio uklonjenog amonijaka ustalio se na $98 \%$. Eliminacija amonijaka povezana je s promjenom $\mathrm{pH}$. Prednosti su biološkog uklanjanja plinova s neugodnim mirisom: niska potrošnja energije, visoka učinkovitost, kompatibilnost s okolišem, jednostavno upravljanje i održavanje, nepostojanje sekundarnog onečišćenja.

\section{Ključne riječi \\ Biotehnologija, plinovi neugodna mirisa, biološko filtriranje, amonijak, kontrola onečišćenja}

College of Environment

Zhejiang University of Technology, Hangzhou

Zhejiang, 310014

Kina
Izvorni znanstveni rad

Prispjelo 1. ožujka 2017. Prihvaćeno 26. lipnja 2017. 